\title{
Towards a risk-based typology for transnational education
}

\section{INTRODUCTION}

Transnational education (TNE), also termed cross-border or offshore education, represents a rapidly expanding activity for UK universities. In 2012/13, there were 598,925 students studying 'wholly overseas' for the award of UK higher education institutions, compared with 425,260 foreign students enrolled in on-campus programmes (HESA n.d.). UK universities provide education to TNE students in third countries through a variety of delivery channels, including offering programmes by distance-learning, establishing international branch campuses (IBCs) and working with a foreign partner to develop, teach and/or assess degrees overseas.

For example, the University of London and the Open University offer their distance-learning programmes across the world, each with approximately 40,000 TNE students in 2012/13 (HEIDI n.d.). The University of Nottingham provides the best-known example of a UK university which has developed IBCs, with satellite campuses in Semenyih (Malaysia) and Ningbo (China). The University of Staffordshire has taken the lead in offering its degrees through foreign partners, with 13,000 students studying offshore in this way in 2012/13 (HEIDI n.d.).

The key challenge for universities, regulators and policymakers with TNE is quality assurance (Castle and Kelly 2004, Craft 2004, Stella 2006, Edwards et al 2010). The reputations of individual universities and national higher education systems are, in large part, based on the perceived quality of their academic awards. Providing education across borders exposes the UK universities to varying degrees of reputational risk. Distance-learning courses may be compromised by online fraud (eg, learners using friends to complete assessments). Maintaining quality control in IBCs may be more difficult because managers and staff operate in an alien culture far from the home campus. Partnership arrangements may be undermined by the 'principal-agent' problem, with the partner colleges (agents) having different objectives (eg, profit maximisation rather than academic quality) from the awarding UK universities (principals). 
There are well-known examples of the reputational damage to universities of failed TNE ventures. In 2004, the ‘UK e-University’ was wound up, after having spent $£ 50 \mathrm{~m}$ of public money, but attracting only 900 students (House of Commons 2005). In 2007, the University of New South Wales abruptly announced that it was closing its UNSW Asia campus in Singapore, amid concerns that the venture was financially ill-founded (Observatory on Borderless Higher Education 2007). In 2011, the decision was taken to close the University of Wales, after official investigations revealed that it was unable to assure the quality of education in its 130 partner colleges (Henry 2011).

In the UK, the Quality Assurance Agency (QAA) uses a typology that distinguishes between three main types of TNE and two sub-types: 1) distance-learning, 2) IBCs and 3) partnerships, which are sub-divided into 3a) franchises and 3b) validated centres. While the precise nomenclature around the world varies, this basic typology is widely used in the TNE literature (eg, Knight 2007; Drew et al 2006; Drew et al 2008; Ziguras and McBurnie 2008; Middlehurst et al 2009; Naidoo 2009). This typology is believed to provide a useful framework for quality assurance, as the degree of control that is transferred to a local partner significantly increases as universities move from distance-learning towards validation, raising the risk of reputational damage.

The value of a typology is that it makes the world easier to understand, in this case by grouping clusters of TNE arrangements with the same general characteristics together and, in quality assurance terms, viewing each type through the same risk management lens. This paper suggests, however, that the currently dominant typology for TNE activity is being challenged by the way that universities are entering into increasingly complex transnational partnerships.

It argues that there is a need for a more multidimensional typology, which focuses on the factors that give rise to the risk of reputational damage, rather than categorising a TNE arrangement on the basis of its form. It employs an exploratory research design to identify the different dimensions of transnational partnerships and offers an alternative typology drawing on partnership theory and transaction cost analysis. 


\section{LITERATURE REVIEW}

TNE involves students remaining in their home country while studying at a foreign university (McBurnie and Ziguras 2009, Burgess and Berquist 2012). This form of higher education embraces 'any teaching or learning activity in which the students are in a different country (the host country) to that in which the institution providing the education is based (the home country). This situation requires that national boundaries be crossed by information about the education, and by staff and/or educational materials' (Global Alliance for Transnational Education 1997, p1).

TNE has been growing, although because few governments, with the notable exceptions of the UK and Australia, record the enrolments of TNE students by their home universities, reliable data are scarce (Naidoo 2009). The literature has identified a range of drivers of TNE activity, including the home university seeking to build a global brand (Wilkins and Huisman 2012), universities supporting capacity building in the host countries, often encouraged by the host governments (Verbik and Merkley 2006, Knight 2011) and commercial revenue generation (Bennell and Pearce 2003, Knight 2007).

As noted above, both regulatory bodies like the UK's QAA and the higher education literature generally recognises four distinct forms of TNE (Bennell and Pearce 2003; Knight 2007; Drew et al 2008). For ease of reference, this is termed the '4F' typology, which categorises TNE activities into the 'four forms' of distance-learning, IBCs, franchising and validation. Although there are a variety of other forms of transnational academic cooperation (eg, articulation/progression agreements, joint, dual and double degrees), these are essentially institutionalised forms of international student exchange and are excluded from the definition of TNE for present purposes. 
Higher Education, 2015, 69(1), pp.1-18 (this version post-print / final draft post-refereeing)

\section{The 4F typology}

\section{Distance-learning}

Historically, distance-learning was carried out using 'correspondence' courses. For example, the University of London has been providing international distance-learning degrees since 1858. Since the advent of the internet in the early 1990s, textbook-based correspondence courses have been steadily replaced by on-line provision (Altbach and Knight 2007). In principal, the university could retain complete control over the admission, teaching and assessment of students, but in practice distance learning often requires a network of local partners or agents to market degrees and provide local support for students. For example, the UK's largest provider of distance learning, the Open University, has partnerships with colleges across the world which support 37,000 of its 53,000 students (Open University n.d.).

\section{International branch campus}

An IBC is a foreign satellite campus, which delivers and awards the degrees of the university. Getting a clear-cut definition is, as Lane and Kinser (2012) note, 'a fairly slippery subject', as IBCs vary from full-blown satellite campuses like the University of Nottingham Ningbo to small executive education training centres (eg, the Chicago Booth School of Business in Singapore). The Observatory for Borderless Higher Education (OBHE) regularly surveys and reports on trends in IBCs (eg, Garrett 2002, Garrett and Verbik 2004, Larsen et al 2004, Verbik and Merkley 2006, Gore 2012, Lawton and Katsomitros 2012). The Cross-Border Education Research Team (C-BERT) also maintains a register of IBCs (C-BERT n.d.).

Most IBCs operate with a local partner, often a property development company which provides and maintains the physical infrastructure. To keep down operating costs, a proportion of the academic staff are normally locally employed. The IBC is typically subject to the quality assurance regime of the host country. These features necessarily reduce the control of the IBC by the home university. 


\section{Franchise}

In a franchise, also commonly called 'twinning' (Edwards et al 2010), a foreign partner is authorised to deliver the university's degree on its behalf (Yorke 1993). With a 'pure' franchise, the degree title, syllabus, teaching materials and assessment are all closely aligned with that of the 'mother' degree on the home campus. In practice, the university may allow variation to accommodate local circumstances (eg, modules on local business law to reflect the different legal environment). Critically, however, the home university cedes much greater control to the partner than in an IBC, since the managers and the academic and administrative staff are employees of the partner organisation.

\section{Validation}

In a validation, a foreign partner develops and delivers its own degree which is 'validated' by the university. Validation goes beyond accreditation, since the university is authorising the partner to offer its own programme as if it were a degree of the awarding university. Validation involves the greatest transfer of control from the awarding university to its overseas partner, since the latter determines the curriculum, admission, teaching and assessment (subject to oversight by the awarding university) as well as employing the staff.

\section{The 4 F typology and reputational risk}

As the control over academic quality is increasingly transferred to the foreign partner, the risk of reputational damage to the home university is likely to increase (see Figure 1). This means that the $4 \mathrm{~F}$ typology provides, in principle, a useful framework for categorising TNE activities from a quality assurance perspective. 
FIGURE 1

Reputation risk versus transfer of control

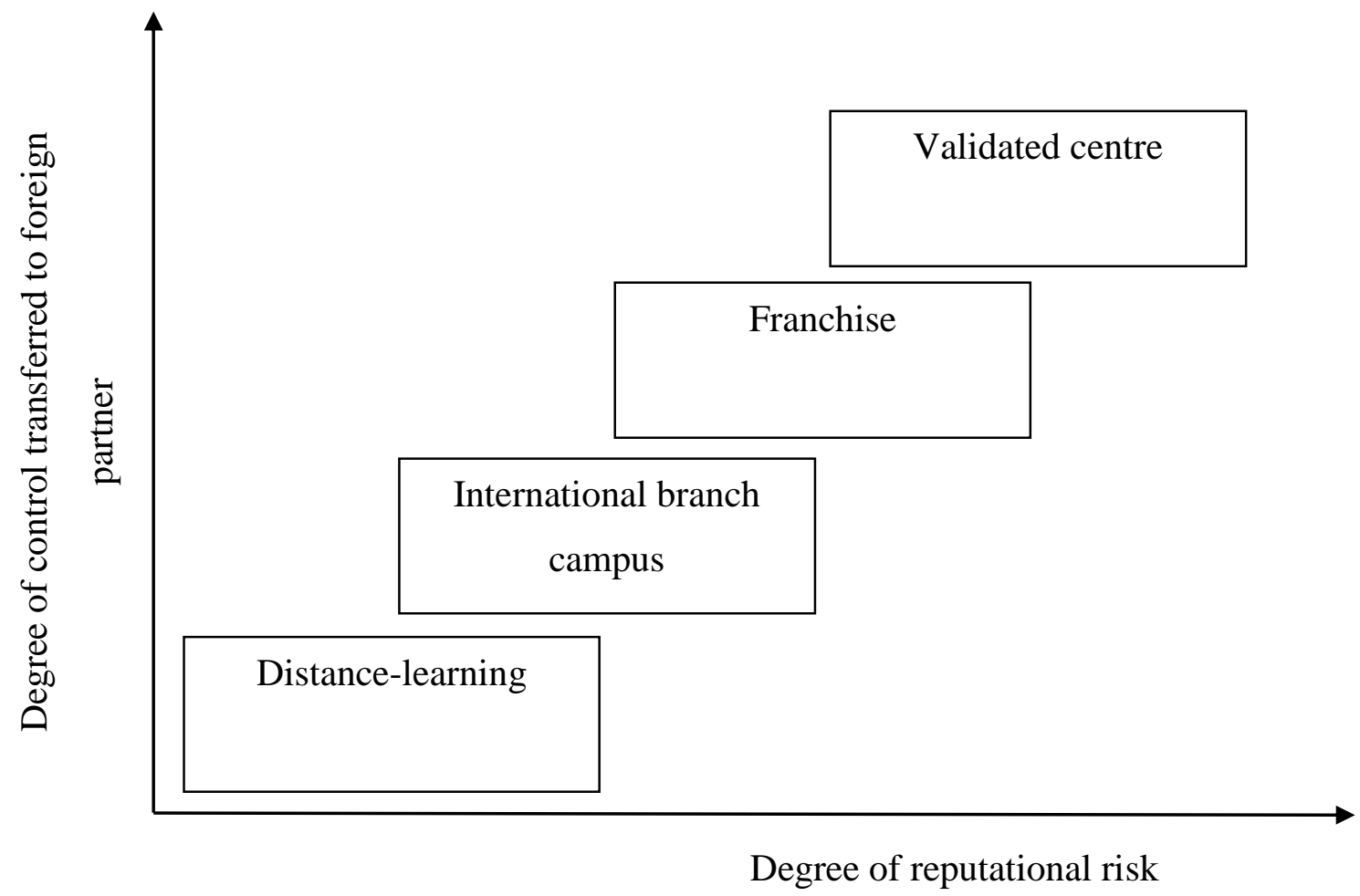

\section{Perspectives from partnership theory}

The organisational development literature on partnerships provides an alternative starting point to consider a typology of TNE. This literature develops typologies by mapping partnerships along various dimensions (eg, Waddock 1991, Selin 1999, Smith and Wohlstetter 2006). These typologies 'propose one or more dimensions of a concept as helpful for describing it and how it interacts with other phenomena' (Moore and Koontz 2003, p452).

Within the higher education literature, this broad approach has been used to develop typologies to categorise inter-university associations. For example, using case studies of universities from a wide range of countries, Neave (1992) classified university cooperation in terms of the degree of complexity in the cooperative arrangements: a) mono-disciplinary linkages, b) exchange partnerships, c) network partnerships, d) multidisciplinary networks and e) consortia. 
Waechter (2000) examined approximately 50 international associations of universities and classified them according to the nature of their members: a) associations of universities, b) associations of associations from higher education, c) associations of individual members, d) regional associations and e) associations with members that had members from both higher education and other sectors.

De Wit (2001) similarly developed a typology of academic associations based on the nature of the membership: a) associations based on individual membership, b) associations of senior academic managers, based on office and c) associations of institutional members. Berkens (2010) built on these approaches to develop a typology for 'international inter-organisational arrangements in higher education', with three dimensions: a) size and scope, b) composition and integration of activities, c) the intensity of collaboration.

Some authors have stressed the role of trust and power asymmetry in inter-university partnerships. Kinser and Green (2009), for example, argue that sustainable partnerships must be based on a spirit of cooperation and trust. Others (eg, Maselli et al 2006, Bradley 2007, Olsson 2008) suggest that asymmetric power relations, seen most commonly in research partnerships between North and South universities, will tend to lead to the breakdown of the partnership over time. Organisational theory suggests this may be because "power-based control' is an ineffective way of encouraging the subordinate partner to share tacit knowledge and expertise (Inkpen and Beamish 1997).

Outside higher education, there have been a number of studies which have attempted to categorise organisational partnerships, rather than associations. These arguably offer a more useful starting point for a new TNE typology, because partnerships are usually formed to carry out a joint activity. In contrast, many associations are loose networking groups for the sharing of information and best practice. While there are a number of different dimensions used by studies in a wide range of organisational settings, the following appear to be the most widely used and are most applicable to university TNE activities: 
1. Composition: this categorises a partnership by the number and diversity of the partners involved (Moore and Koontz 2003).

2. Structure: this is a related dimension that focuses on the nature of the partnership agreement, its degree of formality and the extent to which it is underpinned by legally binding contracts (McQuaid 2000).

3. Scope: this refers to the range of activities covered by the partnership and the term of the agreement (Margerum 2008).

4. Function: this is concerned with the goals of the partnership and what it is intended to achieve (Frank and Smith 2000).

5. Process: this covers the means by which these goals are to be achieved, including the responsibilities and autonomy of each partner (Waddock 1991).

6. Outcome: this addresses the question of whether the outcome of the partnership is a process or a product (Long and Arnold 1995).

In quality assurance terms, the key question is whether the positioning of a TNE partnership along each of these six dimensions provides a useful insight into the 'riskiness' of the arrangement. Before considering this question, it is instructive to turn to transaction cost analysis to understand the fundamental reasons why a TNE partnership may, in principle, expose the university to reputational risk.

\section{Perspectives from transaction cost analysis}

Business strategy research has tended to view internationalisation through the lens of transactions costs. In a seminal article, Coase (1937) argued that an organisation incurs transactions costs (eg, the opportunity cost of management time and the associated legal fees of negotiating, monitoring and enforcing a contract) as a result of entering commercial 
relationships with third parties. If there is 'market failure' (for example, because it is hard for the organisation to monitor the quality of the service it has contracted its partner to provide), these transactions costs will be high and the commercial relationship risky.

Williamson (1975) suggested two reasons for such market failure, in the form of 'bounded rationality' and 'opportunism'. Bounded rationality qualifies the normal assumption in economics that humans act rationally in their own self-interest, by recognising that there are limits to a person's ability to gather and process information. The more complex the nature of the partnership, the more this bounded rationality leads to the inability to make fullyinformed decisions. Opportunism refers to the tendency for individuals to seek personal gain by exploiting an information asymmetry to provide misleading (eg, partial or selective) information to their partner. Fear of such opportunism raises the transactions costs of monitoring the performance of the partner.

The transaction costs approach also provides an alternative perspective on the relationship between partnership performance and power asymmetry. As Muthusamy and White (2006) note, from 'a transactions cost economics, however, a partner's relative power and control in an alliance is considered significant for enhancing commitment and minimizing other party's opportunistic behaviour' (p.812). Although TNE partnerships are collaborative ventures, they are different from, say, an inter-university research partnership, in that they are inherently unbalanced, with the greater power and reputational risk necessarily residing with the home university which awards the qualification, rather that the TNE partner.

The critical insight is that it is market failure that leads to reputational damage for the home university in a TNE partnership. Put differently, increasing risk of market failure directly leads to increasing risk of reputational damage. This suggests that, from a quality assurance perspective, TNE partnerships might be positioned along the six dimensions suggested by partnership theory according to increasing risk of market failure:

1. Composition: the less aligned the missions of the partners, the greater the risk of market failure resulting from opportunism. 
Higher Education, 2015, 69(1), pp.1-18 (this version post-print / final draft post-refereeing)

2. Structure: the more complex the structure of the partnerships, the greater the risk of market failure resulting from bounded rationality.

3. Function: the more commercially oriented the partnership, the greater the risk of market failure resulting from opportunism.

4. Scope: the broader the scope of the arrangement (from single degree to multiple degrees, the greater the market risk resulting from bounded rationality.

5. Process: the greater the transfer of control from the university to the partner, the greater the market risk resulting from both bounded rationality and opportunism.

6. Outcome: the broader the collaboration and the more ambitious its goals, the greater the risk of market failure, primarily resulting from bounded rationality.

\section{RESEARCH QUESTION}

There are two related research questions:

1. Does the existing 4F typology adequately capture the diversity and complexity of TNE?

2. Does partnership theory and transaction cost analysis provide the basis for a 'better' typology of TNE?

\section{METHOD}

The study uses an exploratory research design to answer the two research questions. For the first question, a number of 'experts' were invited to contribute short 500 word case studies of a TNE partnership with which they are directly involved, In this case study, they were requested to highlight the most important features of the transnational partnership. The 
structure of the case study was deliberately open, to avoid responses being constrained by preconceived views on the important features of a TNE partnership.

The participants were members of the Linkedin.com (www.linkedin.com) community, all of whom are employed in managing TNE partnerships and known to the author. The participants were chosen to provide the broadest coverage possible, in terms of the countries involved in the partnerships. Individualised requests were sent to approximately 100 'connections' with senior roles in TNE. The response rate (in terms of reply) was approximately $80 \%$, of whom about 40 were able to provide the case studies within the time frame. Of these, 30 were in a usable form, with the remainder discarded because of poor English or incompleteness. These cases were analysed to see how they aligned with the $4 \mathrm{~F}$ typology. These case studies were very 'rich', providing a powerful test of the tractability of the $4 \mathrm{~F}$ typology, but were too brief and unrepresentative to provide the basis for building an alternative typology.

For the second question, the data used were the 40 overseas QAA institutional audits from the period 2009-12. Each year, QAA undertakes a survey of all UK universities with TNE provision in a given country. During this period, the countries reviewed were China (2012), Singapore (2011), Malaysia (2010) and India (2009). Based on the survey results, the QAA selects ten university partnerships each year to be audited, with sample designed to capture the diversity of the activities being undertaken. For example, the sample frame will include different forms of TNE activity (IBC, franchise, validation) as well as universities with different missions (eg, research-intensive, teaching-intensive).

The UK, together with Australia, is the market leader in TNE and dominates the global market. It is one of the few countries that systematically records the number of TNE students enrolled at its universities and undertakes offshore quality assessments. In terms of the sample frame, Malaysia, Singapore and China are, in that order, the largest host countries for TNE activity. India is the fastest growing and, potentially, the largest TNE market. Malaysia and Singapore have encouraged TNE as a way of establishing themselves as educational hubs to attract students from across the region, while China and India view TNE as 'capacity absorbing' to complement and, through competition, enhance the domestic higher education 
sector. These 40 case studies thus provide a representative sample across four of the most important TNE markets and the typology which emerges can be considered generalizable.

The 40 audit reports were analysed using the six dimensions identified in the review of partnership theory. As each audit report was analysed, codes were developed for the steps along each dimension (composition, structure, function, scope, process and outcome). These were gradually refined and supplemented during the analysis, then sequenced according to the estimated risk of market failure. The result was a coded set of steps along each of the six dimensions.

\section{RESULTS}

\section{Limitations of the $4 \mathrm{~F}$ typology}

The analysis of the 30 Linkedin.com case studies revealed the extraordinary diversity and complexity of the TNE partnerships that have developed around the world. Although about half the partnerships involved a UK university, the host countries represented included a wide spectrum, from highly developed countries (eg, Czech Republic, Hong Kong, Italy, Malaysia, Singapore) to developing nations (eg, Botswana, Kazakhstan, Madagascar, Uzbekistan).

In terms of the 4F typology, there were numerous examples of partnerships which had characteristics of two or more types. For instance, the University of Northampton has a set of three bilateral partnerships with the Vietnamese National University in Ho Chi Min City (HCMC), Da Nang University and the Hanoi University of Science and Technology. Under this arrangement, the Vietnamese universities teach the first part of the Northampton MBA (franchise), while the final stage is taught by Northampton staff that travel out to Vietnam for short, intensive blocks. The entire course is supported by an extensive Northampton-based virtual learning environment (VLE, which is distance-learning), while the Vietnamese students come to Northampton for a summer school (which is conventional 'export education' rather than TNE). 
In Ghana, the University of Leicester offers a range of distance-learning degrees, but these are managed by a local partner that markets the programme, recruits students and provides tutorial support, classrooms and access to facilities (akin to a franchise). Leicester staff regularly travel to Ghana to carry out intensive block teaching to support the distancelearning materials while students can opt to study at the Leicester campus.

These case studies also provide examples of deep transnational partnerships which do not fit neatly into any type. For example, Peking University School of Transnational Law (SLT) operates what it terms a 'sole venture'. SLT has been established as an autonomous organisation by Peking University. It has partnerships with 12 leading law schools from eight countries, as part of which international adjunct faculty develop and deliver a bilingual four-year programme which prepares students for international legal practice. The international partners offer SLT's students opportunities for study abroad and international internships. Because the Juris Doctor and Juris Master degrees are awarded by SLT, this is not distance-learning, an IBC, a franchise or a validation. But the degrees offered depend absolutely on SLT maintaining deep, multidimensional TNE partnerships.

\section{Towards a new typology}

Turning to the development of an alternative typology, the following sections provide an attempt to establish the degree of risk of market failure for each of the six dimensions of a TNE partnership, based on the analysis of the 40 QAA case studies.

\section{Composition}

Composition refers to the nature of the TNE partner. For the UK universities studied in the sample, there are a broad range of partners, including private companies, private for-profit education companies, public universities (autonomous and under state control) and government ministries. To illustrate this diversity, consider the following examples: 
- Staffordshire University: partnership with autonomous public university (University of Madras).

- London Metropolitan University: partnership with state-controlled public university (Shanghai University of Traditional Chinese Medicine).

- London South Bank University: partnership with a public polytechnic (Nanyang Polytechnic) and a public health care provider (Singapore General Hospital).

- University of Wales: partnership with a not-for-profit theological college (TCA College, Singapore).

- University College Plymouth St Mark and St John: partnership with government ministry (Malaysian Ministry of Education).

- University of the West of England: partnership with private, for profit education company (Brickfields Asia College).

The risk of market failure is likely to increase the greater the divergence between the mission of the UK university and its partner. In partnerships between autonomous public universities, there is generally a shared mission in terms of achieving teaching and research excellence and enhancing international reputation. Public and not-for-profit colleges may have a broadly similar mission in terms of teaching, but place a lower weight on research and reputation. Government ministries have political goals, which may align with those of the UK university (eg, promoting the quality of teaching), but are subject to change during the political cycle. For-profit private colleges have commercial objectives. 
TABLE 1

Composition and risk of market failure

\begin{tabular}{|c|c|c|}
\hline 1. Autonomous public university & \multirow{8}{*}{ Increasing risk of } & \multirow{8}{*}{ market failure } \\
\hline 2. State-controlled public university & & \\
\hline 3. Public college & & \\
\hline 4. Not-for-profit college & & \\
\hline 5. Government ministry & & \\
\hline 6. Private university & & \\
\hline 7. Private college & & \\
\hline 8. Private company & & \\
\hline
\end{tabular}

\section{Structure}

There are a number of ways that NTE partnerships are structured. Although the agreements are almost universally formal and contractual in nature, they can extend from a limited bilateral agreement to multilateral agreements. Similarly, the partnership agreement might be the only agreement that the university and the partner is involved with, whereas in other cases either or both have a multitude of other arrangements. For example:

- University of Warwick, Singapore Institute of Manufacturing Technology and Singapore Institute of Management: this is a multilateral agreement, involving the university and two partners, a public research institute and private, for-profit university.

- Bradford University and Institute for Integrated Learning in Management (IILM): this is a bilateral agreement, where the university has other agreements but the partner does not.

- University of London International Programmes and Singapore Institute of Management: this is a bilateral agreement, in which both parties have other agreements. 
The risk of market failure is likely to increase with the complexity of the relationship. The lowest risk is where there is a straightforward bilateral arrangement between the university and the partner and neither party has any other arrangements. As the number of parties to the agreement increase, the complexity is bound to increase to accommodate the different objectives and circumstances of the additional partners. Similarly, the relationship becomes potentially harder for the university to manage when the partner has multiple other agreements, each of which may impose different obligations and constraints on the partner which may be in conflict. Finally, the more partnership agreements the university has, the greater the pressure on management time of dealing with diverse agreements and the greater the risk that one fails.

TABLE 2

Structure and risk of market failure

\begin{tabular}{|l|l|}
\hline 1. Bilateral agreement & \\
\hline 2. Multilateral agreement & \\
\cline { 1 - 2 } 3. University has other agreements & \\
\cline { 1 - 2 } 5. Both parties have other has other agreements & \\
\hline
\end{tabular}

\section{Function}

Function is concerned with the goals of the partnership (ie, what it is intended to achieve). The literature review noted three broad goals for the development of TNE partnerships, namely to enhance the home university's global reputation (eg, by building a global brand name or enhancing its research productivity by access to new academic talent and sources of research funding), to achieve a developmental objective in terms of capacity-building in the host market or to achieve commercial objectives. To illustrate

- University of Nottingham Ningbo: this partnership with the Wenli Education Group is intended to promote the University of Nottingham as a global organisation and to position 
it as research partner with the Chinese government. Its strategic objective is to create an 'international university...[in which] our three campus networks constitute a unique transnational teaching and learning environment hosting the largest number of international students of any British university' (University of Nottingham 2010, p8).

- Staffordshire University and the University of Madras: this is a capacity-building 'development partnership', aimed at knowledge transfer to allow the partner to develop expertise in the area of sustainable development.

- University of Wales and Fazley International College: this is a straightforward commercial partnership, in which the university validates the degrees of a private, forprofit college.

It is likely that the risk of market failure increases as the function of the partnership moves from reputational, when the activities of the partnership will tend to be limited (and aligned) to high quality teaching and research, through developmental to purely commercial, when decisions will primarily be taken in the interests of maximising short-term profits. This is because the more commercially oriented the function, the greater the risk of short-termism (especially if the entry and exit costs are low) and opportunism on the part of the partner.

TABLE 3

Function and the risk of market failure

\begin{tabular}{|ll|l|}
\hline 1. & Reputational goal & \\
2. & Developmental (capacity-building) goal & \\
\hline 3. Commercial goal &
\end{tabular}

\section{Scope}

Scope refers to the range of activities covered by the partnership and the term of the agreement. In the partnerships studied, the scope varied from a component of a degree, 
typically the 'top-up' programme, through single degrees to a comprehensive range of undergraduate and postgraduate degrees. For example:

- London South Bank University, Nanyang Polytechnic and Singapore General Hospital: partnership involving the franchise of a single top-up degree from a polytechnic diploma.

- University of the West of England and Brickfields Asia College: partnership involving a single degree.

- Sheffield Hallam University and KBU International College: partnership involving a range of degrees from different faculties at the university.

- University of Liverpool and Xi'an Jiaotong University: partnership involving a comprehensive range of degrees from most faculties at undergraduate and postgraduate levels.

It is likely that the broader the scope of the partnership, the higher the risk of market failure. This is because the difficulty of assuring quality and compliance with the agreement increases with the number and diversity of degrees covered by the partnership.

TABLE 4

Scope and the risk of market failure

\begin{tabular}{|ll|l|}
\hline 1. & Single top-up degree & \multirow{2}{*}{ Increasing risk of } \\
\hline 2. & Single degree & \\
\cline { 1 - 1 } 3. & Multiple degrees from one school/faculty & \\
\cline { 1 - 2 } 4. & Multiple degrees from multiple schools/faculties & \\
\hline
\end{tabular}




\section{Process}

Process covers the means by which these goals are to be achieved, including the responsibilities and autonomy of each partner. In the partnerships studied, these varied from the partner being responsible only for 'back-office' support services to the partner designing, teaching and assessing a university's degree. For example:

- Durham University and Fudan University: Durham delivers a distance-learning degree, with teaching support and assessment provided by its own staff on a 'flying faculty' basis. Admissions are managed by the university. Fudan provides classrooms, administrative support, English language training and marketing.

- Harper Adams University and Beijing University of Agriculture: the degrees are jointly designed, the university provides quality assurance, but the partner undertakes the teaching and assessment.

- Open University and LASALLE College of the Arts: the partner designs, teaches and assesses the degree; the university provides only quality assurance.

It seems likely that the risk of market failure increases the more that key processes are contracted to the partner, in particularly admissions, teaching, assessment and curriculum design. Table 5 suggests that the risk is minimised if the university controls marketing+ (ie, marketing plus all the other processes below) and maximised if the university only controls quality assurance.

While Table 5 is consistent with a transactions cost approach to market failure, it implies that the more asymmetrical the power relationship between the home university and the partner, the lower the risk of market failure. As noted in the literature review, there is a counterview from organisational theory that the greater the power asymmetry between the partners, the less likely the partnership is to endure. One way of reconciling these alternative perspectives is that the risk of market failure associated with the process dimension may decline over time, as trust between the partners is built, so that sustainable partnerships tend to be associated 
with more symmetrical sharing of control. Nonetheless, at any given point in time, the greater the share of control retained by the home university, the lower the risk of market failure.

TABLE 5

Process and the risk of market failure

\begin{tabular}{|l|l|}
\hline 1. University controls marketing+ & \\
\cline { 1 - 2 } 2. University controls admissions+ & \\
\hline 3. University controls teaching: tutor support+ & \\
\cline { 1 - 2 } 4. University controls teaching: instruction+ & \\
\cline { 1 - 2 } 5. University controls assessment+ & \\
\cline { 1 - 2 } 7. University controls curriculum design+ & \\
\hline
\end{tabular}

\section{Outcome}

In this context, the outcome of the partnership can be either a process or a product. In the case of TNE partnerships, the outcomes vary from building a sustainable, long-term partnership for the mutual benefit of both the university and the partner (process) to simply being the provision of an education service (or product). In practice, all TNE partnerships involve some degree of both outcomes. For example:

- University of Warwick, Singapore Institute of Manufacturing Technology and Singapore Institute of Management: while this partnership provides an education service (product), the primary outcome is the development of broader research collaboration between the university and the research partner (Singapore Institute of Manufacturing Technology).

- Queen Margaret University and International Institute of Hotel Management: this partnership also provides a product (a top-up degree), but the main outcome is to support the partner to become a leading hospitality management school (ie, institutional capacitybuilding). 
- University of Wales and TCA College: the primary outcome from this partnership is the education service. There is little scope to develop any wider form of cooperation between the university and the partner, with the former offering only a commercial validation service to the latter.

It is likely that the greater the emphasis on process as an outcome, the greater the risk of market failure. This is because the outcome is terms of product can be more easily specified and monitored, in terms of the number of students enrolled, the number of students graduating, the number of degrees offered within the partnership, etc. Broader collaboration in terms of joint research is much harder to achieve, success is harder to measure and socalled 'mission drift' an attendant risk the loftier and less-articulated the vision.

\section{TABLE 6}

Outcome and risk of market failure

\begin{tabular}{|ll|r|}
\hline 1. Primarily product-based outcome: education service & $\begin{array}{r}\text { Increasing risk of } \\
\text { failure }\end{array}$ \\
\cline { 1 - 2 } 2. Both product-based and process-based outcomes &
\end{tabular}

\section{DISCUSSION}

The review of the 30 Linkedin.com case studies reveals that there is a rich diversity in the nature of the partnerships, as well as considerable variability in the complexity of the arrangements. The dominant 4F typology cannot capture either this diversity or complexity. This is primarily because many of the partnerships are multidimensional, typically transcending the boundaries between distance-learning, IBC, franchise and validation. For example, some partnerships blend validating the early years of a degree with franchising the final year, supporting the whole degree with distance-learning. The answer to the first research question is that the current typology fails to do justice to the richness, diversity and complexity of many TNE partnerships. 
Does partnership theory and transactions accost analysis provide the basis for a better typology of TNE? The alternative typology is based on the analysis of 40 TNE partnerships in China, Singapore, Malaysia and India, using a matrix to assess the risk of market failure of a TNE partnership along six dimensions: composition, structure, function, scope, process and outcome. This typology essentially provides a way of classifying TNE partnerships in terms of a multidimensional risk profile. For risk management and quality assurance purposes, this is a more promising approach, since it teases out the primary sources of the risk of market failure, rather than presuming that one type (eg, validation) is necessarily riskier than another $(\mathrm{eg}, \mathrm{IBC})$.

To illustrate this point, consider two cases of a franchised operation: University College Plymouth St Mark and St John (Marjon) and Sheffield Hallam University. Both institutions offer franchised degrees in Malaysia. Yet in terms of the alternative typology developed, they can be seen as completely different in almost every respect.

Marjon has a partnership with the Malaysian Ministry of Education which dates back to 1983. It is essentially a Malaysia government development project, designed to build capacity in Malaysia teaching training institutes. The project includes primary English language teacher education and the development of curricula and materials. The franchised degree operates with two Malaysian institutes, Institut Perguruan Gaya (IPG) and Institut Perguruan Kota Bharu (IPKB). Malaysian students study for three years at Marjon and then take their final year at either IPG or IPKB, where they are taught by local staff supported by Marjon. They are awarded a BEd (Hons) Teaching English as a Second Language (TESL) from Marjon. The wider development project also involves a number of other universities from the UK, Australia and New Zealand.

Sheffield Hallam University began its partnership with KBU International College in Malaysia in 2004. It franchises a number of degrees (eg, BEng (Hons) Electrical and Electronic Engineering, BSc (Hons) Computer and Network Engineering and BA (Hons) Accounting) on a $3+0$ basis. $\mathrm{KBU}$ is a private higher education institution, which was set up in 1990 by the First Nationwide Group. KBU also offers franchised degrees from two other 
Higher Education, 2015, 69(1), pp.1-18 (this version post-print / final draft post-refereeing)

UK universities and has 23 degrees from across its three UK partners. Table 7 summarises the differences between the two franchises in terms of the new typology.

TABLE 7

Two UK university franchises in Malaysia

\begin{tabular}{|l|l|l|}
\hline & UC Plymouth St Mark and St John & Sheffield Hallam University \\
\hline Composition & Government ministry & Private college \\
\hline Structure & Multilateral agreement & Both parties have other agreements \\
\hline Function & Developmental goal & Commercial goal \\
\hline Scope & Single degree & $\begin{array}{l}\text { Multiple degrees from multiple } \\
\text { schools/faculties }\end{array}$ \\
\hline Process & University controls teaching: tutor- & $\begin{array}{l}\text { University controls curriculum } \\
\text { design+ }\end{array}$ \\
\hline Outcome & Support+ & Primarily product-based \\
\hline
\end{tabular}

This difference can be illustrated graphically by assigning a numerical value to the position of each university along each of the six dimensions and normalising this value onto a scale of one to ten (where 1 is the lowest risk of market failure and 10 is the highest): see Figure 2. 
FIGURE 2

The different shape of two Malaysian franchises

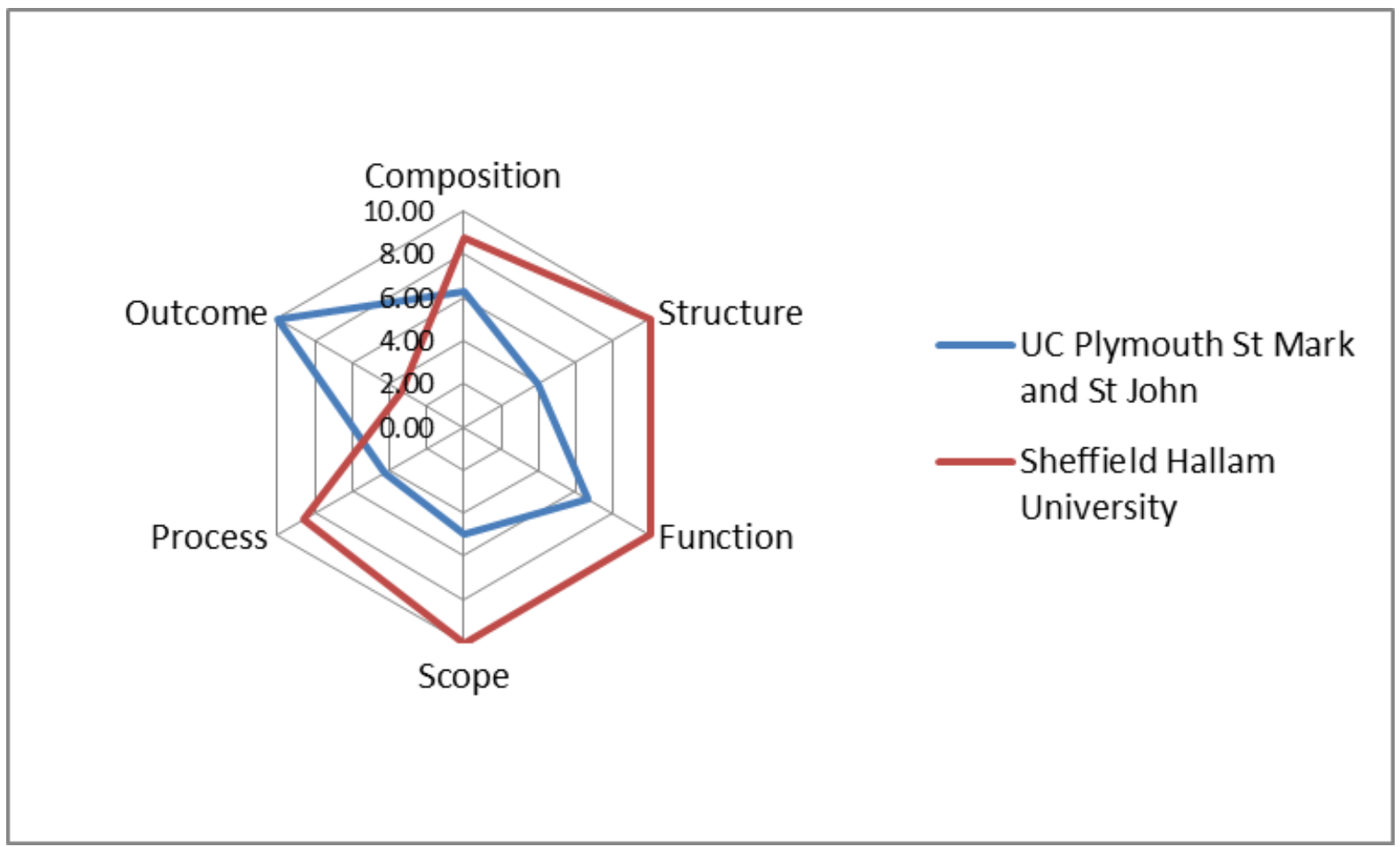

By providing a typology that measures a TNE partnership by the risk of market failure along six dimensions, it is possible to provide a more meaningful picture than the $4 \mathrm{~F}$ approach. It embraces and extends earlier approaches to categorising inter-university cooperation which classify arrangements primarily by the number and diversity of partners and the intensity of the collaboration to bring in issues of process, control and the objectives of those involved (eg, commercial or developmental).

The use of a matrix does not naturally lead to the emergence of a small set of distinct types, as in the $4 \mathrm{~F}$ typology, because partnerships have become so multidimensional and nuanced. One way of operationalizing this matrix into a more conventional typology would be to categorise TNE partnerships as 'low risk', 'medium risk' and 'high risk' based on the sum of the normalised scores for each of the six dimensions (eg, low risk $=0-20$, medium risk $=21$ 40, high risk $=41-60)$. On this basis, the Marjon partnership would be medium risk (normalised index $=36.2$ ) while Sheffield Hallam would be high risk (index $=50.7$ ). There is scope for further research to develop this approach. 


\section{CONCLUSION}

TNE is a rapidly developing phenomenon and the organisational forms of TNE are growing more complex and sophisticated. The conventional 4F typology for classifying TNE activity is, as a consequence, losing explanatory power. In part this is because the boundaries between the neatly pigeonholed types of TNE are breaking down and becoming blurred. In a microcosm of globalisation more widely, increasing connectivity, both virtual and physical, erodes the distinction between different forms of TNE.

The alternative typology developed based on the analysis of 40 TNE partnerships in China, Singapore, Malaysia and India uses a matrix, assessing the risk of market failure of a TNE partnership along six dimensions: composition, structure, function, scope, process and outcome. This new typology provides a more powerful way of categorising a TNE partnership in terms of its risk profile.

\section{REFERENCES}

Altbach, P. and Knight, J. (2007). The internationalization of higher education: motives and realities. Journal of Studies in International Education, 11(3-4), 290-305.

Beerkens, E. (2002). International inter-organisational arrangements in higher education: towards a typology. Tertiary Education and Management, 8(4), 297-314.

Bennell, P. and Pearce, T. (2003). The internationalisation of higher education: exporting education to developing and transitional economies. International Journal of Educational Development, 23(2), 215-232.

Bradley, M. (2007). North-South research partnerships: challenges, responses and trends - a literature review and annotated bibliography. Working Paper 1, IDRC Canadian Partnerships Working Paper Series. Ottawa: International Development Research Centre. Available from: http://idl-bnc.idrc.ca/dspace/bitstream/10625/36539/1/127716.pdf [Accessed: 13 December 2014]. 
Burgess, P. and Berquist, B. (2012). Cross-border delivery: programs, programs, and providers. In Darla K. Deardorff, D., de Wit, H., Heyl, J. and Adams, T. (eds.). The SAGE handbook of international higher education. London: SAGE, 325-342.

C-BERT (n.d.) Branch Campus Listing (Updated March 17, 2014). Available from: http://www.globalhighered.org/branchcampuses.php [Accessed 28 March 2014].

Castle, R. and Kelly, D. (2004). International education: quality assurance and standards in offshore teaching: exemplars and problems. Quality in Higher Education, 10(1), 51-57.

Coase, R. (1937). The nature of the firm. Economica, 4(16), pp.386-405. Available from: http://onlinelibrary.wiley.com/doi/10.1111/j.1468-0335.1937.tb00002.x/pdf [Accessed 4 April 2013]

Craft, A. (2004). The assessment of quality risks in collaborative provision. Quality in Higher Education, 10(1), 25-29.

De Wit, H. (2002). Internationalization of higher education in the United States of America and Europe: a historical, comparative, and conceptual analysis. London: Greenwood Press.

Drew S., Tang N., Poole G., Willis B. (2006). Trans-national education - UK higher education institutions' response to increasing global demand: summary report. Manchester: British Council.

Drew, S., McCaig, C., Marsden, D., Haughton, P., McBride, J., McBride, D., Willis, B. and Wolstenholme, C. (2008). Trans-national education and higher education institutions: exploring patterns of HE institutional activity. London: Department for Innovation, Universities and Skills. 
Higher Education, 2015, 69(1), pp.1-18 (this version post-print / final draft post-refereeing)

Edwards, J., Crosling, G. and Edwards, R. (2010). Outsourcing university degrees: implications for quality control. Journal of Higher Education Policy and Management, 32(3), 303-315.

Frank, F. and Smith, A. (2000). The partnership handbook. Minister of Public Works and Government Services, Canada. Available from: http://publications.gc.ca/collections/Collection/MP43-373-1-2000E.pdf [Accessed 5 March 2013].

Garrett, G. and Verbik, L. (2004). Transnational delivery by UK higher education, Part 1: data and missing data. Redhill: Observatory on Borderless Higher Education. Available from: http://www.obhe.ac.uk/documents/view_details?id=63 [Accessed 6 June 2012].

Garrett, R. (2002). International branch campuses: scale and significance. Redhill: Observatory on Borderless Higher Education. Available from: http://www.obhe.ac.uk/documents/view_details?id=574 [Accessed 20 September 2012].

Global Alliance for Transnational Education (1997). Certification Manual. Cited in: Adams, T., 1998. The operation of transnational degree and diploma programs: the Australian case. Journal of Studies in International Education, 2(1), 3-22.

Gore, T. (2012). Higher education across borders: models of engagement and lessons from corporate strategy. Redhill: Observatory on Borderless Higher Education. Available from: www.obhe.ac.uk/documents/download?id=895 [Accessed 20 August 2012].

Henry, J. (2011). University of Wales abolished after visa scandal. The Telegraph. Available from:

http://www.telegraph.co.uk/education/educationnews/8843200/University-of-Walesabolished-after-visa-scandal.html [Accessed: 17 January 2014].

HEIDI (n.d.) Higher Education Information Database for Institutions. Available from: https://heidi.hesa.ac.uk/home.aspx [Accessed 28 March 2014]. 
HESA (n.d.) Free online statistics - students \& qualifiers. Available from: http://www.hesa.ac.uk/content/view/1897/239/ [Accessed 28 March 2014].

House of Commons (2005). Education and Skills Committee: UK e-University (Third Report of Session 2004-05). Available from: http://www.publications.parliament.uk/pa/cm200405/cmselect/cmeduski/205/205.pdf [Accessed 20 December 2013].

Inkpen A. and Beamish, P. (1997). Knowledge, bargaining power, and the instability of international joint ventures. Academy of Management Review, 22(1), 177-202.

Kinser, K. and Green, M. (2009). The power of partnerships: a transatlantic dialogue, Washington D.C.: American Council on Education. Available from: http://www.eua.be/publications/reference-publications.aspx [Accessed: 15 December 2013].

Knight, J. (2007). Cross-border tertiary education: an introduction. In Vincent-Lancrin, S. (ed.) Cross-border tertiary education: a way towards capacity development, Organisation for Economic Cooperation and Development and The World Bank, 21-46.

Knight, J. (2011). Education Hubs: A Fad, a Brand, an Innovation? Journal of Studies in International Education, 15(3), 221-240.

Lane, J. and Kinser, K. (2012). International branch campuses: one definition to rule them all? Available from: http://chronicle.com/blogs/worldwise/international-branch-campusesone-definition-to-rule-them-all/29051 [Accessed 6 February 2013].

Larsen, K., Momii, K. and Vincent-Lancrin, S. (2004). Cross-border higher education: an analysis of current trends, policy strategies and future scenarios. Redhill: The Observatory on Borderless Higher Education. Available from: http://www.obhe.ac.uk/documents/view_details?id=49 [Accessed 19 October 2012]. 
Higher Education, 2015, 69(1), pp.1-18 (this version post-print / final draft post-refereeing)

Lawton, W. and Katsomitros, A. (2012). International branch campuses: data and developments. Redhill: Observatory on Borderless Higher Education. www.obhe.ac.uk/documents/download?id=894 [Accessed 22 August 2012].

Long, F. and Arnold, M. (1995). The power of environmental partnerships. London: Dryden Press.

Margerum, R. (2008). A typology of collaboration efforts in environmental management. Environmental Management, 41(4), 487-500.

Maselli D., Lys J-A., and Schmid J. (2006). Improving impacts of research partnerships. Swiss Commission for Research Partnerships with Developing Countries. Berne: KFPE GEOGRAPHICA BERNENSIA. Available from: www.kfpe.ch/download/KFPE_ImpactStudy-final.pdf ] Accessed13 December2013.[

McBurnie, G. and Ziguras, C. (2009). Trends and future scenarios in programme and institution mobility across borders. In Higher Education to 2030 Volume 2: Globalization. Paris: OECD, 89-108.

McQuaid, R. (2000). The theory of partnerships: why have partnerships? In Osborne, S. (ed.) Public-private partnerships: theory and practice in international practice. London: Routledge, $9-35$.

Middlehurst, R., Woodfield, S., Forland, H., and Fielden, J. (2009). Universities and international higher education partnerships: making a difference. London: Million+. Available from: http://www.millionplus.ac.uk/research/index [Accessed 24 August 2012]

Moore, E. and Koontz, T. (2003). Research Note - a typology of collaborative watershed groups: citizen-based, agency-based, and mixed partnerships. Society \& Natural Resources: An International Journal, 16(5), 451-460. 
Higher Education, 2015, 69(1), pp.1-18 (this version post-print / final draft post-refereeing)

Muthusamy, S. and White, M. (2006). Does power sharing matter? The role of power and influence in alliance performance. Journal of Business Research, 59(7), 811-819.

Neave, G. (1992). Managing higher education international cooperation: strategies and solutions. UNESCO. Available from:

http://unesdoc.unesco.org/images/0009/000986/098679eb.pdf [Accessed: 30 May 2013].

Naidoo, V. (2009). Transnational higher education: a stock take of current activity Journal of Studies in International Education, 13, 310-330.

Observatory on Borderless Higher Education (2007). A miscalculated level of risk? UNSW Asia announces its unexpected closure. Available from: http://www.obhe.ac.uk/documents/view_details?id=192 [Accessed 16 June 2012].

Olsson, B. (2008). Symmetry and asymmetry in research partnerships: lessons from 20 years' experience. NORRAG News 41, December, 78-80. Available from: http://www.norrag.org/en/publications/norrag-news/online-version/the-new-politics-ofpartnership-peril-or-promise/detail/symmetry-and-asymmetry-in-research-partnershipslessons-from-20-years-experience.html (Accessed 14 December 2013].

Open University (n.d.) Facts and figures. Available from: http://www.open.ac.uk/about/main/the-ou-explained/facts-and-figures [Accessed 17 January 2014].

Selin, S. (1999). Developing a typology of sustainable tourism partnerships. Journal of Sustainable Tourism, 7(3\&4), 260-274.

Smith, J. and Wohlstetter, P. (2006). Understanding the different faces of partnering: a typology of public-private partnerships. School Leadership and Management, 26(3), 249268. 
Higher Education, 2015, 69(1), pp.1-18 (this version post-print / final draft post-refereeing)

Stella, A. (2006). Quality assurance of cross-border higher education. Quality in Higher Education, 12(3), 257-276.

University of Nottingham (2010). Strategic Plan 2010-15. Available from:

http://www.nottingham.ac.uk/about/documents/universityofnottinghamstrategicplan201015.pdf [Accessed 20 December 2012].

Verbik, L. and Merkley, C. (2006). The International Branch Campus - Models and Trends. Redhill: Observatory on Borderless Higher Education. Available from: http://www.obhe.ac.uk/documents/view_details?id=34 [Accessed 20 November 2012].

Waddock, S.A. (1991). A typology of social partnership organizations. Administration and Society, 22(4), 480-515.

Waechter, B. (2000). Handbook on European associations in higher education: a practical guide to academic networks in Europe and beyond. Brussels: Academic Cooperation Association.

Wilkins, S. and Huisman, J. (2012). The international branch campus as transnational strategy in higher education. Higher Education, 64(5), 627-645.

Williamson, O. (1975). Markets and hierarchies: analysis and antitrust implications: a study in the economics of internal organization. London: Collier Macmillan.

Yorke, M. (1993). Quality assurance for higher education franchising. Higher Education, 26(2), 167-182.

Ziguras, C., and McBurnie, C. (2008). The impact of trade liberalization on transnational education. In Wallace, M. and Dunn, L. (Eds.), Teaching in transnational higher education: enhancing learning for offshore international students. Oxford: Routledge. 